\title{
Prevalence of Nutritional Risk at Admission in Internal Medicine Wards in Portugal: The Multicentre Cross- Sectional ANUMEDI Study
}

\author{
Prevalência de Risco Nutricional à Admissão na \\ Enfermaria de Medicina Interna em Portugal: Estudo \\ Transversal Multicêntrico ANUMEDI
}

\author{
Ricardo MARINHO ${ }^{* 1}$, Ana PESSOA*2 Marta LOPES ${ }^{3}$, João ROSINHAS ${ }^{4}$, João PINHO ${ }^{5}$, Joana SILVEIRA ${ }^{6}$, \\ Ana AMADO ${ }^{7}$, Sandra SILVA ${ }^{8}$, Bruno OLIVEIRA ${ }^{9,10}$, Aníbal MARINHO ${ }^{11}$, Harriët JAGER-WITTENAAR ${ }^{12,13}$ \\ Acta Med Port 2021 Jun;34(6):420-427 - https://doi.org/10.20344/amp.13182
}

\section{ABSTRACT}

Introduction: Disease-related undernutrition is highly prevalent and requires timely intervention. However, identifying undernutrition often relies on physician judgment. As Internal Medicine wards are the backbone of the hospital setting, insight into the prevalence of nutritional risk in this population is essential. We aimed to determine the prevalence of nutritional risk in Internal Medicine wards, to identify its correlates, and to assess the agreement between the physicians' impression of nutritional risk and evaluation by Nutritional Risk Screening 2002.

Material and Methods: A cross-sectional multicentre study was performed in Internal Medicine wards of 24 Portuguese hospitals during 2017. Data on demographics, previous hospital admissions, primary diagnosis, and Charlson comorbidity index score were collected. Nutritional risk at admission was assessed using Nutritional Risk Screening 2002. Agreement between physicians' impression of nutritional risk and Nutritional Risk Screening 2002 was tested by Cohen's kappa.

Results: The study included 729 participants (mean age $74 \pm 14.6$ years, $51 \%$ male). The main reason for admission was respiratory disease. Mean Charlson comorbidity index score was $5.8 \pm 2.8$. Prevalence of nutritional risk was $51 \%$. Nutritional risk was associated with admission during the previous year (odds ratio $=1.65,95 \%$ confidence interval: $1.22-2.24$ ), solid tumour with metastasis (odds ratio $=4.73,95 \%$ confidence interval: $2.06-10.87$ ), any tumour without metastasis (odds ratio $=2.04,95 \%$ confidence interval: 1.24 3.34 ), kidney disease (odds ratio $=1.83,95 \%$ confidence interval: $1.21-2.75$ ), peptic ulcer (odds ratio $=2.17$, 95\% confidence interval: $1.10-4.25$ ), heart failure (odds ratio $=1.51,95 \%$ confidence interval: $1.11-2.04$ ), dementia (odds ratio $=3.02,95 \%$ confidence interval: $1.96-4.64$ ), and cerebrovascular disease (odds ratio $=1.62,95 \%$ confidence interval: $1.12-2.35$ ). Agreement between physicians' evaluation of nutritional status and Nutritional Risk Screening 2002 was weak (Cohen's kappa $=0.415, p<0.001$ ).

Discussion: Prevalence of nutritional risk in the Internal Medicine population is very high. Admission during the previous year and multiple comorbidities increase the odds of being at-risk. Subjective physician evaluation is not appropriate for nutritional screening.

Conclusion: The high prevalence of at-risk patients and poor subjective physician evaluation suggest the need to implement mandatory nutritional screening.

Keywords: Hospitalization; Internal Medicine; Malnutrition; Nutritional Assessment

\section{RESUMO}

Introdução: A subnutrição associada à doença apresenta grande morbimortalidade e necessita de intervenção precoce. Contudo, a sua identificação assenta frequentemente no julgamento médico. Adicionalmente, sendo a enfermaria de Medicina Interna o pilar do hospital, é essencial maior conhecimento sobre o estado nutricional desta população. Os objetivos consistiram em determinar a prevalência de risco nutricional na enfermaria de Medicina Interna, identificar fatores relacionados e avaliar a concordância entre a avaliação do risco nutricional baseada no julgamento médico e no Nutritional Risk Screening 2002.

Material e Métodos: Estudo transversal multicêntrico realizado nas enfermarias de Medicina Interna de 24 hospitais portugueses durante 2017. Foram avaliadas características demográficas, internamentos prévios, diagnósticos principais, índice de comorbilidades de Charlson e habilitações literárias. O risco nutricional à admissão foi avaliado usando o Nutritional Risk Screening 2002. A concordância entre o julgamento médico e o Nutritional Risk Screening 2002 foi testado usando o teste kappa de Cohen (k).

\footnotetext{
* Co-primeiros autores.

1. Serviço de Medicina Interna. Centro Hospitalar Universitário do Porto. Porto. Portugal.

2. Serviço de Medicina Interna. Centro Hospitalar Médio Ave. Vila Nova de Famalicão. Portugal.

3. Serviço de Hematologia Clínica. Centro Hospitalar Universitário do Porto. Porto. Portugal.

4. Serviço de Medicina Interna. Unidade Local de Saúde de Matosinhos. Matosinhos. Portugal.

5. Unidade de Nutrição. Centro Hospitalar Médio Ave. Vila Nova de Famalicão. Portugal.

6. Escola Superior de Biotecnologia. Universidade Católica Portuguesa. Porto. Portugal.

7. EEIG Ecotrophelia Europe. Avignon. France.

8. Independent Researcher. Porto. Portugal.

9. Faculdade de Ciências de Nutrição e Alimentação. Universidade do Porto. Porto. Portugal.

10. Laboratório de Inteligência Artificial e Apoio à Decisão. Instituto de Engenharia de Sistemas e Computadores, Tecnologia e Ciência. Porto. Portugal.

11. Unidade de Cuidados Intensivos. Centro Hospitalar Universitário do Porto. Porto. Portugal.

12. Research Group Healthy Ageing, Allied Health Care and Nursing. Hanze University of Applied Sciences. Groningen. The Netherlands.

13. Department of Oral and Maxillofacial Surgery. University of Groningen. University Medical Center Groningen. Groningen. The Netherlands.

$\triangle$ Autor correspondente: Ricardo Marinho. ricardomarinho.medicina@chporto.min-saude.pt

Recebido: 13 de janeiro de 2020 - Aceite: 28 de julho de 2020 - Online issue published: 01 de junho de 2021

Copyright @ Ordem dos Médicos 2021
} 
Resultados: Foram incluídos 729 participantes (idade média $74 \pm 14,6$ anos, $51 \%$ do sexo masculino). A principal causa de admissão foi doença respiratória. O índice de comorbilidades de Charlson médio foi 5,8 $\pm 2,8$. A prevalência de risco nutricional foi $51 \%$. O risco nutricional associou-se a internamento recente (odds ratio $=1,65,95 \%$ intervalo de confiança: 1,22 - 2,24), neoplasia sólida metastizada (odds ratio $=4,73,95 \%$ intervalo de confiança: $2,06-10,87$ ), neoplasia não metastizada (odds ratio $=2,04$, 95\% intervalo de confiança: 1,24 - 3,34), doença renal (odds ratio = 1,83, 95\% intervalo de confiança: 1,21 - 2,75), úlcera péptica (odds ratio = 2,17, 95\% intervalo de confiança: 1,10 - 4,25), insuficiência cardíaca (odds ratio = 1,51, 95\% intervalo de confiança: 1,11 - 2,04), demência (odds ratio $=3,02,95 \%$ intervalo de confiança: 1,96 - 4,64) e doença cerebrovascular (odds ratio = 1,62, 95\% intervalo de confiança: 1,12 - 2,35). A concordância entre julgamento médico e Nutritional Risk Screening 2002 foi fraca $(k a p p a$ de Cohen = 0,415, $p<0,001)$. Discussão: A prevalência de risco nutricional na enfermaria de Medicina Interna é muito elevada. Admissão recente e múltiplas comorbilidades aumentam a probabilidade de risco nutricional. A avaliação subjetiva do médico não é apropriada para o rastreio nutricional. Conclusão: A elevada prevalência de doentes em risco e baixa precisão da avaliação subjetiva médica sugerem a necessidade de implementar rastreio nutricional obrigatório a nível nacional.

Palavras-chave: Avaliação Nutricional; Desnutrição; Hospitalização; Medicina Interna

\section{INTRODUCTION}

Malnutrition/undernutrition has been described as a state resulting from lack of intake or uptake of nutrients that leads to altered body composition and body cell mass, and ultimately to decreased physical and mental function and impaired clinical outcomes from illness. ${ }^{1}$ Worldwide, the prevalence of disease-related undernutrition has been reported to be between $20 \%$ and $50 \%$, depending on the studied population and the criteria used for diagnosis. ${ }^{2}$ Undernutrition has a negative impact on the quality of life and contributes to adverse clinical outcomes, such as increased risk for infections, poor wound healing, longer length of stay in hospital, increased hospital costs, and higher morbidity and mortality rates. ${ }^{3}$ Therefore, screening for undernutrition allows for timely identification and treatment of malnourished patients, thus improving clinical outcomes and costs. ${ }^{4}$

The risk of undernutrition ranges from $33 \%$ to $65 \% .^{5-7}$ In Portugal, the most recent large nationwide study ${ }^{8}$ showed that the prevalence of the risk of undernutrition at hospital admission varied between $29 \%$ and $47 \%$. This study was performed both in medical and surgical patients, but in a given country almost $24 \%$ of the hospital bed-days may be provided by Internal Medicine wards. ${ }^{9}$ Internal Medicine patients appear to have a higher probability of being malnourished, ${ }^{10,11}$ since they are generally older and have multiple comorbidities..$^{9,12,13}$ Additionally, routine nutritional screening is not yet fully enforced across Portugal, making patient nutritional screening rely on the judgment of the attending physician. Therefore, the prevalence and characteristics of Internal Medicine patients at risk for undernutrition remain unclear. Additional knowledge would allow the identification of the most vulnerable patients and optimize their nutritional care. To that end, we aimed to determine the prevalence of the nutritional risk at admission in Internal Medicine wards and to identify the socio-demographic and clinical factors associated with the undernutrition risk. We also aimed to assess the agreement between the physicians' impression of nutritional risk and nutritional risk assessment using the Nutritional Risk Screening (NRS) 2002 score.

\section{MATERIAL AND METHODS}

\section{Study design and population}

The Avaliação Nutricional em Medicina Interna (ANUMEDI) study is a cross-sectional multicentre observational study coordinated by the Internal Medicine Study Group of the Portuguese Society of Enteral and Parenteral
Nutrition (Associação Portuguesa de Nutrição Entérica e Parentérica [APNEP]). Internal Medicine residents from 48 public Portuguese hospitals were asked to join the study through the Portuguese Network of Internal Medicine Residents from the Portuguese Society of Internal Medicine (Sociedade Portuguesa de Medicina Interna). All centres had a local study coordinator and several co-researchers (Internal Medicine residents), who attended a one-day course where the evidence behind nutritional screening and assessment was reviewed, and instructions on how to use the study protocol (including the NRS 2002) were given.

This study included patients aged over 18 years old, consecutively admitted to an Internal Medicine ward less than 72 hours prior to the day of the study, regardless of whether the patient remained admitted or would be discharged on that day. Exclusion criteria were incomplete data and refusal to participate. Data were collected in three different days according to the co-researchers' availability, with an interval of 10 to 15 days between the days of assessment, to allow for new patients to be admitted. In the days of data collection, a member of the scientific committee was available by phone in order to assist the researchers. Data collection started on the $1^{\text {st }}$ of February and finished on $31^{\text {st }}$ December 2017.

Approval from the Director of each Internal Medicine Unit and local ethics committees was obtained. Furthermore, the Portuguese Data Protection Authority authorized the data collection (authorization number 8479/2016). All participating patients or their legal representatives provided written informed consent before enrolment in the study. Data were handled confidentially and anonymously. Data were entered in an online database, for which each co-researcher had a unique login.

\section{Procedures}

The following data were obtained from the electronic medical records: age, sex, hospital and ward admission date, type of admission, primary diagnosis (according to the International Statistical Classification of Diseases and Related Health Problems 10th revision (ICD-10) codes), education level (no education, $4^{\text {th }}$ grade, $9^{\text {th }}$ grade, $12^{\text {th }}$ grade or higher education - defined as a bachelor, masters or doctorate degree), place of residence and past admissions in the previous year. 
Each patient was evaluated by a co-researcher within 72 hours of admission to the ward. Before formal nutritional risk screening evaluation, physicians were asked if they thought the patient was at risk of undernutrition. Subsequently, the NRS 2002 was used to screen for the risk of undernutrition as previously described ${ }^{14}$ and recommended for hospital nutritional screening. ${ }^{15}$ This tool consists of four questions as an initial screening, including body mass index (BMI), weight loss, reduced dietary intake, and severe illness. Patients' weight and height were self-reported. When weight and height could not be reported, and therefore $\mathrm{BMI}$ was not calculated, mid upper arm circumference $<25 \mathrm{~cm}$ was used as surrogate for BMl $<20.5 \mathrm{~kg} / \mathrm{m},{ }^{2}$ as suggested in the NRS 2002 methodology publication. ${ }^{14}$ If the answer to at least one of these questions was positive, the final screening part, which consists of nutrition parameters and grading of severity of disease, was performed. Patients were considered "nutritionally at risk" when the NRS 2002 score was $\geq 3 .{ }^{14}$

The Charlson comorbidity index score ${ }^{16}$ was used to characterize the comorbidity burden of the studied population based on the presence of 19 different scored diagnoses, according to the information described in the patients' clinical records.

\section{Statistical analysis}

Statistical analysis was performed using IBM SPSS Statistics (IBM SPSS Statistics Premium Grad Pack Version 23.0). Categorical variables were represented by frequencies and percentages. Continuous variables were represented by means and standard deviations, or medians with interquartile range (IQR) for variables with skewed distributions. Normal distribution was checked using the Shapiro-Wilk test.

Differences between risk groups (NRS $2002<$ 3 and NRS $2002 \geq 3$ ) were evaluated using the chisquare test for categorical variables, or independent samples $t$-test or Mann-Whitney test for continuous variables, as appropriate. For the individual comorbidities that had a significant $p$-value according to the chisquare test, odds ratio were calculated using univariate logistic regression analysis.

Univariate and backward multivariate logistic regression analysis were used to identify correlates of nutritional risk, as defined by NRS $2002 \geq 3$. According to the current literature on social and medical risk factors for undernutrition, ${ }^{10,11,17,18}$ the variables entered in the backward multivariate logistic regression model were: residence (home versus relative's home versus nursing home versus long term care facility versus others), education level (no education versus $4^{\text {th }}$ grade versus $9^{\text {th }}$ grade versus $12^{\text {th }}$ grade versus higher education), admission during previous year (yes/no), type of admission (admission from emergency department versus admission from other hospital/department versus planned admission), sex, and Charlson comorbid- ity index score. Subsequently, in each step of the backward multivariate logistic regression, variables with a $p$-value $>0.1$ were removed from the model. Age and individual comorbidities were not included as variables in the multivariate analysis, as they are included in the Charlson comorbidity index score. All reported $p$ values are two-tailed, with a $p$-value $<0.05$ indicating statistical significance.

Agreement between physicians' impression of nutritional risk and NRS 2002 was tested by Cohen's kappa (K). Results were classified as: no agreement $(\leq 0.20)$, minimal agreement $(0.21$ $0.39)$, weak agreement $(0.40-0.59)$, moderate agreement $(0.60$ - 0.79), strong agreement (0.80 - 0.90), or almost perfect agreement $(>0.90) .{ }^{19}$

\section{RESULTS}

Of the 48 Portuguese public hospitals invited, 24 participated (11 from the North Region of Portugal, five from the Central Region, seven from the South Region and one from the islands), resulting in 891 patients invited. Of the 162 patients that were excluded, 93 had incomplete data, 66 refused to participate, and three were rejected for other reasons. A total of 729 participants were included in the analysis. Characteristics of the study sample are depicted in Table 1.

Fifty-one percent of the study subjects were male, with a mean age of $74.2 \pm 14.6$ years old. Twenty-three percent of the participants had no education, and $55 \%$ had the $4^{\text {th }}$ grade only. Prior to hospital admission, most of the subjects lived in their own home, followed by a relative's home. Most of the participants were admitted through the emergency department. More than one-third were admitted to a hospital in

Table 1 - Characteristics of the studied participants $(n=729)$ (section 1 of 2$)$

\begin{tabular}{|c|c|}
\hline Characteristics & \\
\hline Male sex, $n(\%)$ & $369(50.6)$ \\
\hline Age (years), mean $\pm S D$ & $74.2 \pm 14.6$ \\
\hline \multicolumn{2}{|l|}{ Education level, n (\%) } \\
\hline No education & $170(23.3)$ \\
\hline $4^{\text {th }}$ grade & $399(54.7)$ \\
\hline $9^{\text {th }}$ grade & $87(11.9)$ \\
\hline $12^{\text {th }}$ grade & $37(5.1)$ \\
\hline Higher education & $36(4.9)$ \\
\hline \multicolumn{2}{|l|}{ Residence, n (\%) } \\
\hline Home & $491(67.4)$ \\
\hline Relative's home & $136(18.7)$ \\
\hline Nursing home & $77(9.9)$ \\
\hline Long term care facility & $10(1.4)$ \\
\hline Others & $20(2.7)$ \\
\hline \multicolumn{2}{|l|}{ Admission type, n (\%) } \\
\hline Admission from emergency department & $636(87.3)$ \\
\hline Transfer from other hospital/service & $76(10.4)$ \\
\hline Planned admission & $17(2.3)$ \\
\hline Admissions during previous year, $\mathrm{n}(\%)$ & $280(38.4)$ \\
\hline Length of stay in the previous year (days), median (IQR) & $15(7-29)$ \\
\hline
\end{tabular}


the previous year, with a median duration of admission of 15 days (IQR 7 - 29 days). The mean Charlson comorbidity index score was $5.8 \pm 2.8$, which represents a mean survival rate of $4.1 \%$ at ten years (ranging from 0 to $77.5 \%$ ) according to this score. ${ }^{16}$ The most frequent causes for hospital admission were

Table 1 - Characteristics of the studied participants $(n=729)$ (section 2 of 2$)$

\begin{tabular}{|c|c|}
\hline \multicolumn{2}{|l|}{ Characteristics } \\
\hline \multicolumn{2}{|l|}{ Primary diagnosis (ICD-10), $\mathrm{n}(\%)$} \\
\hline Diseases of the respiratory system & $234(32.1)$ \\
\hline Diseases of the circulatory system & $204(28.0)$ \\
\hline Diseases of the genitourinary system & $83(11.4)$ \\
\hline Certain infectious and parasitic diseases & $39(5.4)$ \\
\hline Diseases of the digestive system & $32(4.4)$ \\
\hline Neoplasms & $26(3.6)$ \\
\hline Endocrine, nutritional and metabolic diseases & $26(3.6)$ \\
\hline Diseases of the blood and blood-forming organs & $19(2.6)$ \\
\hline Symptoms, signs and abnormal findings & $16(2.2)$ \\
\hline Diseases of the nervous system & $14(1.9)$ \\
\hline Diseases of the skin and subcutaneous tissue & $14(1.9)$ \\
\hline Diseases of the musculoskeletal system & $12(1.7)$ \\
\hline Mental and behavioural disorders & $6(0.8)$ \\
\hline Injury, poisoning and others & $3(0.4)$ \\
\hline Diseases of the eye and adnexa & $1(0.1)$ \\
\hline Charlson comorbidity index, mean \pm SD & $5.8 \pm 2.8$ \\
\hline \multicolumn{2}{|l|}{ Comorbidities (ICD-10) } \\
\hline Heart failure, $n(\%)$ & $265(36.4)$ \\
\hline Chronic obstructive pulmonary disease, $\mathrm{n}(\%)$ & $163(22.4)$ \\
\hline Cerebrovascular disease, $\mathrm{n}(\%)$ & $144(19.8)$ \\
\hline Diabetes without end organ damage, $\mathrm{n}(\%)$ & $135(18.5)$ \\
\hline Dementia, n (\%) & $120(16.5)$ \\
\hline Diabetes with end organ damage, $n(\%)$ & $117(16.1)$ \\
\hline Moderate or severe kidney disease, n (\%) & $117(16.1)$ \\
\hline Any tumour without metastasis, $\mathrm{n}(\%)$ & $77(10.7)$ \\
\hline Acute coronary syndrome, n (\%) & $67(9.2)$ \\
\hline Peripheral vascular disease, $\mathrm{n}(\%)$ & $66(9.1)$ \\
\hline Peptic ulcer, n (\%) & $41(5.6)$ \\
\hline Solid tumour with metastasis, n (\%) & $39(5.4)$ \\
\hline Mild liver disease, n (\%) & $38(5.2)$ \\
\hline Hemiplegia, n (\%) & $36(4.9)$ \\
\hline Connective tissue disease, $\mathrm{n}(\%)$ & $34(4.7)$ \\
\hline Pressure ulcer, n (\%) & $33(4.5)$ \\
\hline Cachexia, n (\%) & $30(4.1)$ \\
\hline Moderate or severe liver disease, $n(\%)$ & $26(3.6)$ \\
\hline Trauma, n (\%) & $12(1.7)$ \\
\hline Lymphoma, n (\%) & $10(1.4)$ \\
\hline Leukaemia, n (\%) & $9(1.2)$ \\
\hline AIDS, n (\%) & $2(0.3)$ \\
\hline
\end{tabular}

ICD-10: International Statistical Classification of Diseases and Related Health Problems $10^{\text {th }}$ revision; IQR: interquartile range; SD: standard deviation respiratory $(32 \%)$, circulatory $(28 \%)$, and genitourinary $(11 \%)$ diseases. The most common comorbidities were heart failure (36\%), chronic obstructive pulmonary disease $(22 \%)$, and cerebrovascular disease $(20 \%)$.

The prevalence of nutritional risk according to the NRS 2002 was 51\%. Demographics and comorbidities per NRS 2002 category are presented in Table 2. In the univariate analysis, age, education level, residence, admission during the previous year, type of admission, and Charlson comorbidity index score significantly differed between NRS 2002 categories.

In the univariate logistic regression analysis, education level, residence, admission during previous year [odds ratio $(\mathrm{OR})=1.65,95 \%$ confidence interval $(\mathrm{Cl})$ : 1.22 - 2.24], type of admission, and Charlson comorbidity index score were associated with nutritional risk. Regarding comorbidities, solid tumour with metastasis (OR $=4.73,95 \% \mathrm{Cl}: 2.06-10.87)$, any tumour without metastasis (OR $=2.04,95 \% \mathrm{Cl}: 1.24-3.34)$, moderate or severe kidney disease $(\mathrm{OR}=1.83,95 \% \mathrm{Cl}: 1.21$ 2.75), peptic ulcer $(\mathrm{OR}=2.17,95 \% \mathrm{Cl}: 1.10-4.25)$, heart failure $(\mathrm{OR}=1.51,95 \% \mathrm{Cl}: 1.11-2.04)$, dementia $(\mathrm{OR}=3.02,95 \% \mathrm{Cl}: 1.96-4.64)$, and cerebrovascular disease $(\mathrm{OR}=1.62,95 \% \mathrm{Cl}: 1.12-2.35)$ were associated with nutritional risk. The multivariate analysis showed that planned admissions decreased the odds of nutritional risk, while increased Charlson comorbidity index score was associated with nutritional risk (Table 3).

A quarter of the patients categorized as being at risk by NRS 2002 were not identified as being at risk by physicians (Table 4). Additionally, physicians wrongly classified $33 \%$ of well-nourished patients as being at nutritional risk. The agreement between physicians' evaluation of nutritional risk and the NRS 2002 was weak $(\mathrm{k}=0.415, p<0.001)$.

\section{DISCUSSION}

Our study showed a very high prevalence of nutritional risk in patients admitted to the Internal Medicine ward $(51 \%)$. Moreover, having multiple comorbidities was associated with nutritional risk. Importantly, we also found a weak agreement between physician nutritional risk evaluation and nutritional risk assessment by NRS 2002.

The prevalence of nutritional risk in our study is higher than reported in other national studies. While the largest Portuguese study to date ${ }^{8}$ showed that the prevalence of nutritional risk at hospital admission varied between $29 \%$ and $47 \%$, another Portuguese study showed a nutritional risk of $42 \% .{ }^{20}$ Worldwide, results are also in line with these studies. A Danish study that also used NRS 2002 showed that just over $40 \%$ of patients admitted to Internal Medicine wards were nutritionally at risk. ${ }^{6}$ A Norwegian study using NRS 2002 also reported a prevalence of nutritional risk of $40 \%$ in Internal Medicine patients. ${ }^{21}$ Recently, an Italian study 
Table 2 - Demographics and comorbidities per NRS 2002 category

\begin{tabular}{|c|c|c|c|}
\hline & $\begin{array}{l}\text { NRS < 3 } \\
(n=358)\end{array}$ & $\begin{array}{l}N R S \geq 3 \\
(n=371)\end{array}$ & $p$-value \\
\hline Male sex, $n(\%)$ & $192(26.3)$ & $177(24.3)$ & $0.110^{1}$ \\
\hline Age (years), median (IQR) & $72(51-93)$ & $81(67-95)$ & $0.001^{2}$ \\
\hline Education level, n (\%) & & & $0.009^{1}$ \\
\hline No education & $65(8.9)$ & $105(14.4)$ & \\
\hline $4^{\text {th }}$ grade & $203(27.8)$ & $196(26.9)$ & \\
\hline $9^{\text {th }}$ grade & $48(6.6)$ & $39(5.3)$ & \\
\hline $12^{\text {th }}$ grade & $24(3.3)$ & $13(1.8)$ & \\
\hline Higher education & $18(2.5)$ & $18(2.5)$ & \\
\hline Residence, n (\%) & & & $0.006^{1}$ \\
\hline Home & $263(36.1)$ & $228(31.3)$ & \\
\hline Relative's home & $51(7.0)$ & $85(11.7)$ & \\
\hline Nursing home & $28(3.8)$ & $44(6.0)$ & \\
\hline Long term care facility & $5(0.7)$ & $5(0.7)$ & \\
\hline Others & $11(1.5)$ & $9(1.2)$ & \\
\hline Admission during previous year, $\mathrm{n}(\%)$ & $116(15.9)$ & $164(22.5)$ & $0.001^{1}$ \\
\hline Type of admission, n (\%) & & & $0.005^{1}$ \\
\hline Admission from emergency department & $308(86.0)$ & $328(88.4)$ & \\
\hline Transfer from other hospital/service & $35(9.8)$ & $41(11.1)$ & \\
\hline Planned admission & $15(4.2)$ & $2(0.5)$ & \\
\hline Charlson comorbidity index, mean \pm SD & $4.87 \pm 2.61$ & $6.74 \pm 2.70$ & $0.001^{3}$ \\
\hline \multicolumn{4}{|l|}{ Comorbidities (ICD-10) } \\
\hline AIDS, n (\%) & $0(0)$ & $2(0.3)$ & $0.499^{3}$ \\
\hline Solid tumour with metastasis, $\mathrm{n}(\%)$ & $7(1)$ & $32(4.4)$ & $0.001^{1}$ \\
\hline Any tumour without metastasis, $\mathrm{n}(\%)$ & $26(3.6)$ & $51(7.0)$ & $0.004^{1}$ \\
\hline Lymphoma, n (\%) & $5(0.7)$ & $5(0.7)$ & $0.955^{3}$ \\
\hline Leukaemia, n (\%) & $3(0.4)$ & $6(0.8)$ & $0.566^{3}$ \\
\hline Moderate or severe liver disease, $n(\%)$ & $15(2.1)$ & $11(1.5)$ & $0.373^{1}$ \\
\hline Mild liver disease, n (\%) & $23(3.2)$ & $15(2.1)$ & $0.148^{1}$ \\
\hline Diabetes with end organ damage, $n(\%)$ & $56(7.7)$ & $61(8.4)$ & $0.840^{1}$ \\
\hline Diabetes without end organ damage, $\mathrm{n}(\%)$ & $56(7.7)$ & $79(10.8)$ & $0.050^{1}$ \\
\hline Moderate or severe kidney disease, n (\%) & $43(5.9)$ & $74(10.2)$ & $0.004^{1}$ \\
\hline Peptic ulcer, n (\%) & $13(1.8)$ & $28(3.8)$ & $0.022^{1}$ \\
\hline Hemiplegia, n (\%) & $15(2.1)$ & $21(2.9)$ & $0.360^{1}$ \\
\hline Dementia, n (\%) & $33(4.5)$ & $87(11.9)$ & $0.001^{1}$ \\
\hline Cerebrovascular disease, $\mathrm{n}(\%)$ & $57(7.8)$ & $87(11.9)$ & $0.011^{1}$ \\
\hline Heart failure, $\mathrm{n}(\%)$ & $113(15.5)$ & $152(20.9)$ & $0.008^{1}$ \\
\hline Connective tissue disease, $n(\%)$ & $17(2.3)$ & $17(2.3)$ & $0.915^{1}$ \\
\hline Chronic obstructive pulmonary disease, $\mathrm{n}(\%)$ & $73(10.0)$ & $90(12.3)$ & $0.210^{1}$ \\
\hline Peripheral vascular disease, $\mathrm{n}(\%)$ & $27(3.7)$ & $39(5.3)$ & $0.162^{1}$ \\
\hline Acute coronary syndrome, $\mathrm{n}(\%)$ & $34(4.7)$ & $33(4.5)$ & $0.778^{1}$ \\
\hline
\end{tabular}

AIDS: acquired immunodeficiency syndrome; NRS 2002: nutritional risk screening 2002; SD: standard deviation; ${ }^{1}$ : analysis of variance using Pearson chi-square test; ${ }^{2}$ : analysis of variance using Mann-Whitney test; ${ }^{3}$ : analysis of variance using independent samples $t$-test.

that used the NRS 2002 reported a prevalence of nutritional risk of $32 \% .{ }^{22}$ Except for the Danish and Norwegian studies, the other studies were performed in medical and surgical patients.
The higher prevalence of nutritional risk in our study can have multiple causes. First, our study was only performed in medical patients, which have a higher chance of being malnourished. ${ }^{10,11}$ This may be caused by the fact that In- 
ternal Medicine patients are older, ${ }^{9,13}$ with studies showing that older age is associated with a higher prevalence of undernutrition. ${ }^{11,17,18,23,24}$ Additionally, these patients have multiple comorbidities that impact on their nutritional status..$^{9,13}$ In our study, we found that cancer, moderate/severe kidney disease, peptic ulcer, heart failure, dementia, and cerebrovascular disease increased the odds of being nutritionally at risk. Previous research also reported that cardiovascular and respiratory diseases, ${ }^{21}$ which are among the most common causes of admission to the Internal Medicine ward, ${ }^{9}$ are associated with nutritional risk. ${ }^{21}$ There are no Portuguese studies performed exclusively on medical patients, making our study the first one to evaluate nutritional risk in internal medicine patients.

We also found that planned admissions appear to decrease the odds of nutritional risk. This may translate into a less severe health state than that seen in patients taken to the emergency department. In fact, NRS 2002 acknowledges severity of disease as a risk factor for nutritional risk, ${ }^{14,15}$ and therefore less acute patients would present with less risk. Additionally, these patients appear to have fewer comorbidities, with a mean Charlson comorbidity index score of 5.18 (as compared to subjects at nutritional risk, with a mean Charlson comorbidity index score of 6.74), which can also impact on nutritional risk. However, this result should be interpreted with caution, given the low number of planned admissions compared to urgent admissions (17 vs 634 subjects).

We found a weak agreement between the physician's impression of nutritional risk and risk assessment made using NRS 2002. This may be explained by the lack of nutritional awareness among physicians in Portugal, also reported in other countries and settings. ${ }^{3}$ Moreover, worldwide, education in clinical nutrition in medical curricula is poor, ${ }^{25}$ which is also likely to contribute to poor recognition of nutritional risk by physicians. However, this raises important implications for clinical practice. In a setting with a high prevalence of nutritional risk where physician evaluation does not adequately and systematically identify at-risk patients, our results call for the need for an urgent implemen-

Table 3 - Univariate and multivariate binary logistic regression for nutritional risk (NRS 2002) ${ }^{3}$

\begin{tabular}{|c|c|c|c|c|c|c|}
\hline \multirow[b]{2}{*}{ Variables } & \multicolumn{3}{|c|}{ Univariate analysis } & \multicolumn{3}{|c|}{ Multivariate analysis } \\
\hline & OR & $95 \% \mathrm{Cl}$ & $p$-value & OR & $95 \% \mathrm{Cl}$ & $p$-value \\
\hline Male sex & 0.79 & $0.59-1.06$ & 0.110 & - & - & - \\
\hline Education level & & & 0.010 & - & - & - \\
\hline No education & 1.00 & & & - & - & - \\
\hline $4^{\text {th }}$ grade & 0.60 & $0.41-0.86$ & & - & - & - \\
\hline $9^{\text {th }}$ grade & 0.50 & $0.30-0.85$ & & - & - & - \\
\hline $12^{\text {th }}$ grade & 0.34 & $0.16-0.71$ & & - & - & - \\
\hline Higher education & 0.62 & $0.30-1.28$ & & - & - & - \\
\hline Residence & & & 0.006 & - & - & - \\
\hline Home & 1.00 & & & - & - & - \\
\hline Relative's home & 1.92 & $1.30-2.84$ & & - & - & - \\
\hline Nursing home & 1.81 & $1.09-3.01$ & & - & - & - \\
\hline Long term care facility & 1.15 & $0.33-4.04$ & & - & - & - \\
\hline Others & 0.94 & $0.38-2.32$ & & - & - & - \\
\hline Admission during previous year & 1.65 & $1.22-2.24$ & 0.001 & - & - & - \\
\hline Type of admission & & & 0.021 & & & 0.025 \\
\hline Admission from emergency department & 1.00 & & & 1.00 & & \\
\hline Transfer from other hospital/service & 1.12 & $0.69-1.78$ & & 1.21 & $0.72-2.02$ & \\
\hline Planned admission & 0.13 & $0.03-0.56$ & & 0.14 & $0.03-0.61$ & \\
\hline Charlson Comorbidity Index & 1.31 & $1.23-1.40$ & $<0.001$ & 1.32 & $1.23-1.41$ & $<0.001$ \\
\hline
\end{tabular}

Education, residence, admission during previous year and sex were excluded during the backward stepwise multivariate regression, as the $p>0.1$. Cl: confidence interval; OR: odds ratio.

Table 4 - Agreement between physician evaluation and NRS 2002

\begin{tabular}{lccc}
\hline & & Physician evaluation & \\
& Well-nourished, $\mathrm{n}(\%)$ & Risk of undernutrition, $\mathrm{n}(\%)$ & Total, $\mathrm{n}(\%)$ \\
\hline NRS 2002 $<3$ & $241(67.3 \%)$ & $117(32.7 \%)$ & $358(100 \%)$ \\
NRS 2002 $\geq 3$ & $96(25.9 \%)$ & $275(74.1 \%)$ & $371(100 \%)$ \\
Total & 337 & 392 & 729 \\
\hline
\end{tabular}

NRS 2002: nutritional risk screening 2002 
tation of mandatory nutritional screening across hospitals. Prior to the beginning of this study, no national screening policies nor government support of home medical nutrition was implemented. However, ongoing efforts are being made to change this. In 2018, and Ministerial Order $6634 / 2018$ was published in the Official Journal, ${ }^{26}$ which stated that all hospitalized adult patients with a length of stay over 24 hours have to be screened with NRS 2002 by a multidisciplinary team. This will allow proper and systematic identification of at-risk patients, allowing nutritional assessment and intervention in order to improve nutritional status and prognosis of patients.

The findings of our study also have economic implications. Identifying at-risk patients is a key starting point for diagnosing undernutrition, ${ }^{1}$ which is also beneficial to our hospitals. Studies have shown that diagnosing, documenting and coding undernutrition can increase hospital reimbursement, since hospital reimbursement relies on the case-mix index. ${ }^{20,27-29}$ Increased hospital reimbursement could facilitate further investment in nutritional care and help compensating the costs associated with undernutrition. ${ }^{29,30}$ Future studies should investigate the cost associated with coding undernutrition, as this could be an incentive to screen, evaluate, and treat malnourished patients.

The major strength of the current study is the large number of participants and the adequate distribution of participating hospitals across different regions of the country, showing a good representation of this specific Portuguese population. The current study also has some limitations. Weight and height were self-reported, which can under- or overestimate results. However, as BMI is just one of multiple parameters used in NRS 2002, this likely did not affect the findings.

\section{CONCLUSION}

The prevalence of nutritional risk in patients admitted to Internal Medicine wards in Portugal is very high. These patients are old and have multiple comorbidities that put them at nutritional risk, which consequently affects their prognosis, particularly of those who had an admission during the previous year and have either a solid tumour with or without metastasis, moderate to advanced kidney disease, peptic ulcer, heart failure, dementia or cerebrovascular disease.

Since physician judgement of nutritional risk identifies less patients at risk, it would be important to implement a nutritional screening policy.

\section{REFERENCES}

1. Cederholm T, Barazzoni R, Austin P, Ballmer P, Biolo G, Bischoff S, et al. ESPEN guidelines on definitions and terminology of clinical nutrition. Clin Nutr. 2017;36:49-64.

2. Barker L, Gout B, Crowe T. Hospital malnutrition: prevalence, identification and impact on patients and the healthcare system. Int $J$ Environ Res Public Health. 2011;8:514-27.

3. Norman K, Pichard C, Lochs H, Pirlich M. Prognostic impact of diseaserelated malnutrition. Clin Nutr. 2008;27:5-15.

4. Gallagher-Allred C, Voss A, Finn S, McCamish M. Malnutrition and clinical outcomes: the case for medical nutrition therapy. J Am Diet Assoc. 1996;96:361-8.

\section{ACKNOWLEDGMENTS}

The authors would like to thank all the study participants for their contribution in this project and Pedro Marcos for the creation of the online database. The authors are also indebted to all Internal Medicine residents who collaborated in the data collection: Adriana Sousa; Ana Carolina Andrade; Ana Catarina Lucas; Ana Gomes; Ana João Carvalho; Ana Lima Silva; Ana Marçal; Ana Pinho; Ana Ponciano; Ana Rita Queirós; Ana Lopes Gonçalves; Andreia Costa; Andreia Pinelo; Bráulio Gomes; Bruna Nascimento; Carlos Anjo; Carmen Pais; Carolina Coelho; Catarina Carvalho; Catarina Castelo Branco; Catarina Machado; Daniel Oliveira; Daniela Carneiro; Daniela Santos; David Garcia; Diogo Pedro; Francisco Gouveia; Helena Gonçalves; Inês Pintassilgo; Isabel Caballero; Joana Costa; Joana Milho; Joana Rigor; Joana Serôdio; João Gomes; João Maia; João Oliveira; João Rua; Joel Pinto; Juliana Sá; Luciana Sousa; Mafalda Pereira; Márcia Silva ; Maria Duarte; Mariana Alves; Marina Boticário Fernandes; Marta Rebocho Alves; Nayive Gomez; Paulo Almeida; Penelope Almeida; Renato Nogueira; Ricardo Fernandes; Rita Quelhas Costa; Rita Neto; Rita Silva; Rosa Cardoso; Rute Martins; Sara Camões; Sara Pinto; Sara Xavier Pires, Vânia Rodrigues; Verónica Guiomar.

\section{PROTECTION OF HUMANS AND ANIMALS}

The authors declare that the procedures were followed according to the regulations established by the Clinical Research and Ethics Committee and to the Helsinki Declaration of the World Medical Association updated in 2013.

\section{DATA CONFIDENTIALITY}

The authors declare having followed the protocols in use at their working center regarding patients' data publication.

\section{CONFLICT OF INTEREST}

All authors have no conflict of interest.

\section{FUNDING SOURCES}

The study was financially supported by Associação Portuguesa de Nutrição Entérica E Parentérica (APNEP).

5. Sauer A, Goates S, Malone A, Mogensen K, Gewirtz G, Sulz I, et al Prevalence of malnutrition risk and the impact of nutrition risk on hospital outcomes: results from nutrition day in the U.S. JPEN J Parenter Enteral Nutr. 2019;43:918-26.

6. Rasmussen $\mathrm{H}$, Kondrup $\mathrm{J}$, Staun M, Ladefoged $\mathrm{K}$, Kristensen $\mathrm{H}$, Wengler A. Prevalence of patients at nutritional risk in Danish hospitals. Clin Nutr. 2004;23:1009-15.

7. Khalatbari-Soltani S, Marques-Vidal P. Impact of nutritional risk screening in hospitalized patients on management, outcome and costs: a retrospective study. Clin Nutr. 2016;35:1340-6.

8. Matos L, Teixeira M, Henriques A, Tavares M, Álvares L, Antunes A, et 
al. Menções sobre o estado nutricional nos registos clínicos de doentes hospitalizados. Acta Med Port. 2007;20:503-10.

9. Verma AA, Guo Y, Kwan JL, Lapointe-Shaw L, Rawal S, Tang T, et al. Patient characteristics, resource use and outcomes associated with general internal medicine hospital care: the General Medicine Inpatient Initiative (GEMINI) retrospective cohort study. CMAJ Open. 2017;5:E842-9.

10. Bonetti L, Terzoni S, Lusignani M, Negri M, Froldi M, Destrebecq A. Prevalence of malnutrition among older people in medical and surgical wards in hospital and quality of nutritional care: a multicenter, crosssectional study. J Clin Nurs. 2017;26:5082-92.

11. Kang M, Kim J, Ryu S, Moon J, Park J, Park J, et al. Prevalence of malnutrition in hospitalized patients: a multicenter cross-sectional study. J Korean Med Sci. 2018;33:e10.

12. Gomes F, Schuetz P, Bounoure L, Austin P, Ballesteros-Pomar M, Cederholm $T$, et al. ESPEN guidelines on nutritional support for polymorbid internal medicine patients. Clin Nutr. 2018;37:336-53.

13. Buurman B, Frenkel W, Abu-Hanna A, Parlevliet J, de Rooij S. Acute and chronic diseases as part of multimorbidity in acutely hospitalized older patients. Eur J Intern Med. 2016;27:68-75.

14. Kondrup J, Rasmussen $\mathrm{H}$, Hamberg O, Stanga Z. Nutritional risk screening (NRS 2002): a new method based on an analysis of controlled clinical trials. Clin Nutr. 2003;22:321-36.

15. Kondrup J, Allison S, Elia M, Vellas B, Plauth M. ESPEN guidelines for nutrition screening 2002. Clin Nutr. 2003:22:415-21.

16. Charlson M, Pompei P, Ales K, MacKenzie C. A new method of classifying prognostic comorbidity in longitudinal studies: development and validation. J Chronic Dis. 1987;40:373-83.

17. Pirlich M, Schutz T, Kemps M, Luhman N, Minko N, Lübke $H$, et al. Social risk factors for hospital malnutrition. Nutrition. 2005;21:295-300.

18. Waitzberg D, Caiaffa W, Correia M. Hospital malnutrition: the Brazilian national survey (IBRANUTRI): a study of 4000 patients. Nutrition.
2001;17:573-80.

19. McHugh M. Interrater reliability: the kappa statistic. Biochem Med. 2012;22:276-82

20. Amaral T, Matos L, Tavares M, Subtil A, Martins R, Nazaré M, et al. The economic impact of disease-related malnutrition at hospital admission. Clin Nutr. 2007;26:778-84

21. Tangvik R, Tell G, Guttormsen A, Eisman J, Henriksen A, Nilsen R, et al. Nutritional risk profile in a university hospital population. Clin Nutr. 2015;34:705-11.

22. Sanson G, Sadiraj M, Barbin I, Confezione C, Matteis DD, Boscutti $\mathrm{G}$, et al. Prediction of early- and long-term mortality in adult patients acutely admitted to internal medicine: NRS-2002 and beyond. Clin Nutr. 2020;39:1092-100

23. Pirlich M, Schutz T, Norman K, Gastell S, Lübke H, Bischoff S, et al. The German hospital malnutrition study. Clin Nutr. 2006;25:563-72.

24. Correia M, Campos A. Prevalence of hospital malnutrition in Latin America: the multicenter ELAN study. Nutrition. 2003;19:823-5.

25. Cole $\mathrm{H}, \mathrm{McGee} U$. Clinical nutrition education in medical schools: results of an ESPEN survey. Clin Nutr. 2017;36:1735.

26. Despacho n. ${ }^{\circ}$ 6634/2018. Diário da República, II Série, n. ${ }^{\circ} 129$ (2018/07/06). p.18713-4

27. Coelho A, Ferreira I, Alves P, Trigo L, Amaral T. O efeito da codificação da desnutrição no financiamento hospitalar. Nutrícias. 2012;12:18-9.

28. Kellett J, Kyle G, Itsiopoulos C, Naunton M, Luff N. Malnutrition: the importance of identification, documentation, and coding in the acute care setting. J Nutr Metab. 2016;2016:9026098.

29. Fernandes A, Pessoa A, Vigário $M$, Jager-Wittenaar H, Pinho J. Does malnutrition influence hospital reimbursement? A call for malnutrition diagnosis and coding. Nutrition. 2020;74:110750.

30. Klek S, Chourdakis M, Bischoff S, Dubrov S, Forbes A, Galas A, et al. Economy matters to fight against malnutrition: Results from a multicenter survey. Clin Nutr. 2017;36:162-9. 